\title{
Strengthening the Function of Prejudicial Institutions and the Implementation Concept of the Judges Institution of Commissioners in the Protection of Suspects Rights
}

\author{
Ari Qurniawan \\ Faculty of Law \\ University of Lampung \\ qurniawanarii@gmail.com
}

\author{
Murdian \\ Faculty of Law \\ University of Lampung \\ qurniawanarii@gmail.com
}

\author{
Anggraini \\ Faculty of Law \\ University of Lampung \\ anggraini.sh@gmail.com
}

\begin{abstract}
The criminal procedure of law, Act Number 8/1981 concerning criminal procedure law which is considered as an Indonesian's masterpiece in criminal law reforming by protecting human rights. One of the forms of protection is protection for the suspect, accordingly, the pretrial institution is regulated on criminal procedure law. However, in its development, although the authority of the pretrial institution has been expanded with the existence of a Constitutional Court judgment, there are still many weaknesses of the pretrial institution, because the pretrial institution, which is a horizontal supervisory institution, only do the only administrative examination, not up to substantive examination. Almost all of the protections in the pretrial institution only giving protection to the rights of suspects, while the rights of victims are neglected in pretrial institutions, especially the rights of victims to obtain certainty and justice in legal proceedings about complaints and statements from the victims. To overcome the fundamental weaknesses of the pretrial institution, a discourse has emerged to implement the Commissioner Judge in the criminal justice system in Indonesia, namely in the Draft of Criminal Procedure Code, which before the ratification of Criminal Procedure Code (KUHAP) had been brought up, but in the end, what was implemented was a pretrial institution. The idea of bringing up the application of the Commissioner Judge again has raised pro and contra opinions from various groups who come up with their respective arguments. In the end, legal reforms in the Indonesian criminal justice system,
\end{abstract}

Keywords-Strengthening, Prejudicial Institutions, The Judges Institution of Commissioners, Protection Of Suspects Rights

\section{INTRODUCTION}

The founding fathers of the nation have agreed to establish an Indonesian state based on the law (rechtsstaat), and not on mere power (machtsstaat), especially in promoting the principle of humanity and the principle of justice within the framework of respecting and protecting human rights (HAM), as well as ensuring the equality of citizens in the world. before the law and government [1].

In the development of law in Indonesia, especially in the development of national criminal law, one of which is in criminal procedural law, Law Number 8 of 1981 was born [2]. Which is considered a masterpiece or masterpiece of the Indonesian nation in the context of reforming criminal law in Indonesia by protecting human rights (HAM), which replaces HIR and $\mathrm{RBg}$ as colonial procedural laws [3]. Based on the idea of respect for human rights (HAM), the enactment of Law Number 8 of 1981 concerning the Criminal Procedure Code, in which there are also arrangements for Pretrial Institutions [4].

Philosophically, the existence of a Pretrial Institution is a means for a person or suspect to obtain justice, where all legal actions against suspects must be based on law, so that the authority given by law to legal officers in carrying out legal actions is not used arbitrarily [3]. Sociologically, pretrial institutions are a means of community justice seekers often complain about the criminal justice process which is considered convoluted so that it often harms justice seekers [5]. Sociologically, pretrial institutions are a means of community justice seekers often complain about the criminal justice process which is considered convoluted so that it often harms justice seekers. Juridically, pretrial institutions are regulated in Chapter X concerning court authority (Articles 77 to 83, and 95, as well as Article 1 point 10 of the Criminal Procedure Code/KUHAP) [6].

The problems that arise are related to the authority of the Pretrial institution, bringing back the idea to apply Preliminary Judges or Commissioner Judges in the Draft Criminal Procedure Code, where the concept 
of the Draft Law on Criminal Procedure Law in 1974 was raised, but in its development, the concept was finally abolished and replaced with a Pre-trial institution and ratified in Law Number 8 of 1981.

Further developments, the concept of a Judge Commissioner or Rechter-Commissaris reappeared in the 2011 Criminal Procedure Code Bill as a substitute for the pre-trial institution that already existed in Law No. 8/1981 [7]. The re-existence of Commissioner Judges in the Draft Criminal Procedure Code to replace the existing Pre-trial institutions in the existing Criminal Procedure Code is associated with the development of the authority of the Pre-trial institutions after the Constitutional Court's decision, causing debate as well as the pros and cons of their respective opinions and arguments. Meanwhile, another opinion is to maintain the Pretrial institution but by strengthening its authority.

\section{PROBLEM}

Based on the explanation of the background above, the problems that need to be discussed and researched are as follows:

- Is the pretrial institution still maintained in the criminal justice system in Indonesia by strengthening the pretrial institution or replacing it with the commissioner judge institution?

- What is the ideal conception of strengthening Pretrial institutions and what is the ideal conception of the application of the Judicial Commissioner in the criminal justice system in Indonesia?

\section{RESEARCH METHODS}

This type of research is normative juridical research, so the research approach to be used is the statute approach, the historical approach, the comparative approach, and the conceptual approach [8] The data collected in the writing of this study was carried out by library research, which was then analyzed qualitatively. Next, the research results are written using descriptive-analytical methods, for further conclusions will be drawn using inductive logic, which is a way of concluding specific rules to general rules [9].

\section{DISCUSSION}

A. Maintaining pre-trial institutions by strengthening pretrial institutions or implementing commissioner judges as a substitute for pretrial institutions in the criminal justice system in Indonesia

Pre-trial institutions regulated in Law Number 8 of 1981 itself have undergone several developments after the decision of the Constitutional Court. Whereas with the development of pre-trial institutions after the
Constitutional Court Decision, namely in the Constitutional Court Decision Number 65/PUUIX/2011 dated April 19, 2012, in the review of Article 83 of the Criminal Procedure Code against the 1945 Constitution[10], making the scope of the Pre-trial Institution expanded into actions in the form of arrest, search, confiscation, investigation, prosecution, termination of investigation and termination of prosecution [11], so that the decision of the Constitutional Court Number 21/PUU-XII/2014 dated 28 April 2015 can be concluded that the scope of pretrial was expanded to include the determination of the suspect as one of the objects of pretrial, including confiscation and search.

Legal reasons put forward by the Constitutional Court in Decision Number 65/PUU-IX, and Decision Number 21/PUU-XII to expand the scope of pretrial is (i) pretrial is a manifestation of the suspect's right to exercise horizontal control over several actions of investigators and public prosecutors, (ii) there is a need to protect the suspect's human rights from acts of actions of investigators and public prosecutors, (iii) there is a need to ensure that the law enforcement process is carried out under its corridors, (iv) there is a need to address the development of problems in the preadjudication process. Based on the review, the four reasons can be applied mutatis mutandis to wiretapping and can be used as justification in expanding the scope of pretrial to include whether wiretapping is legal or not [12].

Regulation of the Supreme Court of the Republic of Indonesia Number 4 of 2016 concerning the Prohibition of Reviewing Pretrial Decisions, in Article 2 has determined the object of Pretrial, namely whether or not an arrest, detention, termination of investigation or termination of prosecution, determination of suspect, confiscation and search, compensation and or rehabilitation for a person whose criminal case is terminated at the level of investigation or prosecution [13].

Thus, based on the Criminal Procedure Code (KUHAP), the Decision of the Constitutional Court of the Republic of Indonesia (MK RI) and its doctrine, as well as the Regulation of the Supreme Court of the Republic of Indonesia Number 4 of 2016 concerning the Prohibition of Reviewing Pretrial Decisions above, it is concluded that the scope of Pre-trial authority is to examine the following matters: whether or not an arrest is made, whether or not detention is legal, whether or not the termination of an investigation is legal, whether or not a prosecution is terminated, whether or not a search is legal, whether or not a confiscation is legal, whether or not the determination of a suspect is legal, whether or not wiretapping is legal, and a request for compensation and/or rehabilitation for a person whose criminal case is terminated at the level of investigation or prosecution. 
Against pretrial decisions, no legal remedies can be requested, either appeal, cassation, or review, because the pretrial decision is final and binding, as stated in the Constitutional Court Decision Number 65/PUUIX/2011 dated April 19, 2011 [14] annul the provisions of Article 83 Paragraph (2) of the Criminal Procedure Code (KUHAP) which abolishes an appeal against a pretrial decision. The Supreme Court has also issued Regulation of the Supreme Court of the Republic of Indonesia Number 4 of 2016 concerning the Prohibition of Reviewing Pretrial Decisions, which in Article 3 states that pretrial decisions cannot be submitted for review. Then in its development, the Supreme Court has issued a Supreme Court Circular Number 2018 concerning the Prohibition of Pretrial Submissions for Suspects who have fled [15]

The authority of the Pretrial Institution based on the Criminal Procedure Code (KUHAP), doctrine, and after the decision of the Constitutional Court of the Republic of Indonesia (MK RI), although it has experienced an expansion of authority, there are still shortcomings or weaknesses, because Pretrial as an institution horizontal supervision of the authority of investigators and public prosecutors in carrying out coercive measures (dwang middelen) in carrying out their authority, is only limited to the functions of procedural administrative supervision or technical administrative juridical formalities. So that the Pretrial cannot test the material truth of the process of coercion by law enforcement officers, because the Pretrial only examines the formality of the coercive effort. The weaknesses or shortcomings of the Pretrial institution are as follows [16]: 1)Court proceedings against pretrial can only be carried out if there are parties who exercise their rights; 2) Not all coercive efforts made by investigators or prosecutors can be tested by Pretrial Judges, because Pretrial Judges only pay attention to fulfilling formal requirements and cannot touch material requirements. So that the Pretrial Judge only examines the Pretrial application to the extent of the administrative fulfillment of the coercive effort; 3) The Pretrial Institution is currently a transplant from the Habeas Corpus concept, but it turns out that both the substance and the mechanism in the Criminal Procedure Code (KUHAP) are not under the basic concept of Habeas Corpus. So that the Judge is not effective in supervising the use of coercive measures and the arbitrariness of the Investigator/Prosecutor; 4) The completion of a very short Pretrial trial, namely 7 (seven) days is very short; 5) The cultural factor of the community is related to the passive nature of pretrial, namely that there are still many people who are reluctant to face law enforcement officers in court, so that many people whose rights are not fulfilled in the criminal justice system, in this case many suspects or victims end up be silent and do not make any effort; 6) Independence of Pretrial Judges in handling Pretrials, both personally and institutionally; 7) If someone is determined as a suspect and without any detention process, the suspect's status often creates legal uncertainty; 8) Pretrial legal force which annuls the status of suspect determination ; 9) Weaknesses in the pretrial procedural law which is less clear; 10) The Pretrial Institution has not provided space for crime victims to examine through Pretrial for the slow followup of reports or complaints from victims, or victims feel that there is discrimination in the handling of reports or complaints made by investigators.

The problems that arise are related to the authority of the pretrial institution, bringing back the idea to apply the Preliminary Examining Judge or Commissioner Judge in the Draft Criminal Procedure Code. The re-existence of Commissioner Judges in the Draft Criminal Procedure Code to replace the existing Pre-trial institutions in the existing Criminal Procedure Code is associated with the development of the authority of the Pre-trial institutions after the Constitutional Court's decision, causing debate as well as the pros and cons of their respective opinions and arguments. The existence of the Commissioner Judge also still needs to be studied, whether the presence of the Commissioner Judge will speed up the law enforcement process which in principle the provisions in the Criminal Procedure Code require a simple, fast, and low-cost judicial process, or whether the presence of the Commissioner Judge will hinder the law enforcement process

The existence of Commissioner Judges in the Draft Criminal Procedure Code which also needs to be reviewed is related to the breadth of the authority of Commissioner Judges, which can lead to abuse of authority, because the position of Commissioner Judges is very central in law enforcement, especially in the preadjudication process. The concept of the Judge Commissioner in the Draft Criminal Procedure Code that needs to be reviewed is related to if there is an allegation of negligence or abuse of authority by the Judge Commissioner, is there an institution such as a Pre-trial institution that is used by justice seekers to test it through a fair judicial process, because the Pre-trial institution the judiciary has been replaced by the Commissioner Judge himself. Then, another problem that needs to be studied in the presence of a Commissioner Judge in the Draft Criminal Procedure Code which replaces the Pre-trial institution in the Criminal Procedure Code,

In addition, the existence of Commissioner Judges in the Draft Criminal Procedure Code, in its implementation is also constrained by human resources, namely the Judges themselves, as well as facilities and infrastructure. Another thing that needs to be studied regarding the existence of the Commissioner Judge in the Draft Criminal Procedure Code, namely if it is applied in the criminal justice legal system in Indonesia, is regarding conflicts of interest or conflicts of interest, both internally within the scope of the District Court itself, as well as externally between the District Court and other agencies. namely the Police and the Attorney General's Office. Because the pre-adjudication process 
through the Commissioner Judge in practice it is very possible that it is not in line with the adjudication stage, namely the trial process itself in the District Court.

Based on the things above, the existence of Commissioner Judges in the Criminal Procedure Code Bill needs to be studied in depth so that a criminal policy can be taken at the legislative stage whether the Commissioner Judge will still be included in the Criminal Procedure Code Bill for further promulgation, or the presence of the Commissioner Judge must be eliminated in the Bill The KUHAP, with one of the considerations is optimizing the Pre-trial institution by eliminating or reducing the weaknesses of the Pre-trial institution which is currently after the decision of the Constitutional Court, the authority of the Pre-trial institution has become very broad even though it essentially does not fulfill the principle of justice. The concept of the Judge Commissioner, which has never been embraced in the Indonesian legal system, is a new thing in legal reform in Indonesia that adheres to the civil law system,

Based on the above, it is necessary to conduct an indepth study whether the Commissioner Judge is needed and has been appropriately applied in the legal system in Indonesia by replacing the Pre-trial institution whose authority has been expanded by the Constitutional Court Decision, or whether to maintain the Pre-trial institution by strengthening the Pre-trial institution in terms of authority, with the concept not only for fulfilling the rights of suspects but also in the concept of fulfilling the rights of victims in the pre-trial stage, so it is hoped that the process of controlling law enforcement in the pre-trial process can touch substantially and not merely procedurally, by providing adequate protection. comprehensive.

\section{B. The ideal concept of strengthening pretrial institutions and the ideal concept of the commissioner judge institution in the criminal justice system in Indonesia}

Pretrial construction as a horizontal supervisory control function of preliminary examination which is part of the criminal justice system in Law Number 8 of 1981 concerning Criminal Procedural Law is already behind the development of society and legal science so that Pretrial is considered no longer fulfilling the principles of certainty, justice, and benefit. With the existence of several decisions of the Constitutional Court regarding the pretrial authority, it is considered that they still do not fulfill the essence of the establishment of a pretrial institution. So that if the pretrial institution is finally determined in the renewal of the national criminal law, in this case in the upcoming Criminal Procedure Code, it is necessary to improve its regulation.

Renewal of pretrial institutions by reconstructing pretrial institutions to strengthen pretrial institutions, the authors try to contribute ideas, with the model of maintaining the authority of pretrial institutions that are currently in effect with all its changes, then fulfill the weaknesses of pretrial institutions, based on the views of Soerjono Soekanto concerning two functions that the law can carry out in society, namely as a means of control (a tool of social control) and as a means of carrying out social engineering (a tool of social engineering). So that pretrial functions as a protection against the arbitrariness of law enforcement officers and pretrial can bring the community to a better legal situation and condition towards community development.

\section{1) Maintaining the authority of Pretrial} institutions

The authority of the pretrial institution based on the Criminal Procedure Code (KUHAP), the Decision of the Constitutional Court of the Republic of Indonesia (MK RI) and doctrine, as well as the Regulation of the Supreme Court of the Republic of Indonesia Number 4 of 2016 concerning the Prohibition of Reviewing Pretrial Decisions above, it is concluded that the scope of Pre-trial authority is to examine the following matters, namely: whether or not an arrest is made, whether or not detention is legal, whether or not the termination of an investigation is legal, whether or not a prosecution is terminated, whether or not a search is legal, whether or not a confiscation is legal, whether or not the determination of a suspect is legal, whether or not wiretapping is legal, and a request for compensation and/or rehabilitation for a person whose criminal case is terminated at the level of investigation or prosecution. This authority should be maintained in the pretrial institution.

\section{2) Adding Pretrial powers}

The strengthening of the pretrial institution can be done by adding the authority of the pretrial institution, by fulfilling the weaknesses of the pretrial institution described above, which allows for changes or additions to the pretrial authority.

- Weaknesses of the Pretrial regarding the trial process of the Pretrial can only be carried out if there are parties who exercise their rights. Judges are only passive in the actions of investigators and prosecutors. In Article 79 of the Criminal Procedure Code (KUHAP) the initiative to submit a pretrial application is from the suspect/proxy. In Article 80 of the Criminal Procedure Code (KUHAP) the initiative for submitting a pretrial application is from the investigator/prosecutor/third party. Article 81 of the Criminal Procedure Code (KUHAP) the initiative to submit a Pretrial application for compensation and or rehabilitation is from the suspect or a third party. In the decision of the Constitutional Court, it is intended that the victim and the community are third parties. 
- Weaknesses in Pretrial regarding the rights of the suspect/his family/proxy may fail during the submission process and pretrial trial as referred to in Article 82 Paragraph (1) letter d of the Criminal Procedure Code (KUHAP). Although in the Constitutional Court Decision Number $102 /$ PUU-XIII/2015 in the judicial review of Article 82 Paragraph (1) letter d of the Criminal Procedure Code (KUHAP) it is declared contrary to the 1945 Constitution and has no binding legal force as long as the phrase that a case has begun to be examined does not mean that the Pretrial request is void when the principal of the case has been delegated and the first trial of the subject matter of the case on behalf of the Defendant/Pretrial Petitioner has begun [17]. The decision in practice at the trial gave rise to different interpretations in the sense of "the case begins to be examined", whether by opening the first trial it is considered that the case has begun to be examined, or when the indictment has been read out in the trial it can be said that the case has begun to be examined, because based on empirical experience often things This has become a matter of debate, causing problems. The model that needs to be updated to answer these problems, is for legal certainty and justice, then a norm must be made within the authority of the pretrial institution that if there is a pretrial application submission then the main case cannot be delegated, and if the main case has already been delegated then the main case must be stopped. the trial process until waiting for the results of the pretrial trial.

- Pretrial Weaknesses regarding not all coercive efforts made by investigators or prosecutors can be tested by Pretrial Judges, because Pretrial Judges only pay attention to fulfilling formal requirements and cannot touch material requirements. So that the Pretrial Judge only examines the Pretrial application to the extent of administrative fulfillment of the forced effort. This problem is emphasized in the Regulation of the Supreme Court of the Republic of Indonesia Number 4 of 2016 concerning the Prohibition of Reviewing Pretrial Decisions, which emphasizes that pretrial examinations only assess formal aspects.

- The authority model of the pretrial institution must give wider authority to pretrial judges, not only assessing the formal aspects and being able to assess the material aspects, as long as there are limitations that pretrial judges can examine the substance or material of the case concerning the pre-adjudication process related to coercive efforts and the investigation process and prosecution, and does not enter the subject matter of the case.
- The weakness of Pretrial regarding Pretrial institutions is currently a transplant from the Habeas Corpus concept, but it turns out that both the substance and the mechanism in the Criminal Procedure Code (KUHAP) are not under the basic concept of Habeas Corpus. So that the judge is not effective in supervising the use of coercive measures and the arbitrariness of the investigator/prosecutor. The matter is the authority of the Preliminary Examining Judge (Commissioner Judge) so that this authority cannot be applied in Pretrial institutions.

- The weakness of the Pretrial regarding the completion of the pretrial trial which is very short, namely 7 (seven) days is very short. The provisions in Article 82 Paragraph (1) letter c of the Criminal Procedure Code (KUHAP) are not intended to ignore the principles of justice which are simple, fast, and low cost, but such time is very difficult for justice seekers in pretrial proceedings. So that the norm for the settlement period should need to be changed by adding a pretrial case settlement period.

- The weakness of Pretrial regarding community cultural factors is related to the passive nature of Pretrial, namely that there are still many people who are reluctant to face law enforcement officers in court, so that many people whose rights are not fulfilled in the criminal justice system, in this case, the suspects or victims are many who finally be silent and do not make any effort. This problem is fundamental and difficult to apply in pretrial norms, this is one of the reasons for the idea of implementing the Judicial Commissioner institution.

- Weaknesses of Pretrial regarding the independence of Pretrial Judges in handling Pretrial, both personally and institutionally. This problem can be overcome by internal guidance in the Supreme Court's coaching system and through the Supreme Court's internal supervision and external supervision. So those pretrial judges are required to be professional and have integrity.

- The weakness of the Pretrial is that if a person is determined as a suspect and without a detention process, the suspect's status often creates legal uncertainty. This is because there is no time limit given by the procedural law regarding the time limit for someone who is designated as a suspect, so it often causes someone to hold the status of a suspect for a long time without any certainty when the status ends, while on the other hand, the investigation process does not progress. meaningful process. Because the investigation is not stopped, the suspect cannot file a pretrial application, except for the pretrial submission because the determination of the 
suspect is valid. This is certainly very detrimental to someone who is designated as a suspect and shackles the freedom of a suspect. Of course, this condition can be used by the authorities to carry out criminalization [1].

- Weaknesses of the Pretrial regarding the legal force of the Pretrial which cancels the status of determining the suspect. If the pretrial decision grants the invalidity of the determination of the suspect, it does not invalidate the investigator's authority to determine the person concerned as a suspect again after at least two new, valid pieces of evidence are different from the previous one (Supreme Court Regulation Number 4 of 2016 concerning the Prohibition of Reviewing Pretrial Decisions) [18]. In practice, many suspects have won the Pretrial application in the invalidity of the determination of the suspect, the investigators again determine the suspect, some even have this happened repeatedly, namely the suspect was appointed repeatedly even though he won the Pretrial application, so there is no legal certainty on the strength of the decision. Pretrial in terms of whether or not the determination of a suspect is legal, sometimes the determination of the suspect depends on the tastes of the investigator [19]. The pretrial weakness must be overcome by making a new norm that for the determination of a suspect against someone who is not detained, a time for the investigation and prosecution process is made up to the delegation to the court, or if the process is not fulfilled then within the specified period the status of the suspect is invalidated. by law and a suspect cannot be made a suspect in the same case.

- Then related to the relative competence of filing pretrial cases using the principle of "actor sequitur forum rei" or the place of submission at the position of the Defendant, even though the Pretrial institution was formed as a horizontal control, the place to submit it should be where the main case is filed or will be filed. So that the pretrial procedural law is less clear and less firm because the pretrial procedural process is similar to civil, whereas pretrial arrangements are regulated in criminal procedural law, namely in the Criminal Procedure Code (KUHAP)[3]. Pretrial procedural law issues should be made separate rules, regarding criminal procedural law, so that Pretrial Judges can take statements from the parties and Pretrial Judges can be active as in the criminal case trial process so that Pretrial Judges can enter the substance area of the pre-trial stage not only - Formal eye examination.

- Weaknesses of Pretrial regarding Pretrial institutions have not provided space for crime victims to examine through Pretrial for the slow follow-up of reports or complaints from victims, or victims feel that there is discrimination in the handling of reports or complaints made by investigators. The Pretrial Institution as part of the Criminal Procedure Code (KUHAP) which at the time it was formed was considered a masterpiece or masterpiece, which provides great protection for the rights of the suspect, but does not protect the rights of the victim. Protection of crime victims is abstract protection or indirect protection which is formulated in a formulaic policy, namely abstract protection that tends to lead to the protection of society and individuals. Attention to protection tends to be on the perpetrator, even though the victim of crime according to Sthepen Schafer is said to be the Cinderella of criminal law [20]. The protection of crime victims in pretrial institutions is only related to the provisions in Article 80 of Law Number 8 of 1981 concerning the Criminal Procedure Code (KUHAP), which states that a request to examine whether or not the termination of an investigation or prosecution is legal can be submitted by an investigator or public prosecutor. or a third party who has an interest in the Head of the District Court by stating the reasons, then confirmed by the Constitutional Court Decision Number 98/PUU-X/2012 in essence that "third party interests" are interpreted as victim-witnesses or reporting parties, non-governmental organizations, or community organizations [21].

- Protection of crime victims in pretrial institutions is only limited to requests for whether or not the termination of investigation or prosecution is legal, but the essential thing that should be regulated in fulfilling the principle of justice for victims of crime is the victim's right to file a pretrial application if the victim's complaint or report is slow or not followed up by the investigator. without clear legal reasons, to eliminate or reduce discrimination or selective discrimination in the handling of cases by investigators.

- The protection of the victims mentioned above, as a manifestation of the principles of justice and equality before the law, provides comprehensive arrangements in pretrial institutions that protect the rights of suspects and victims in a balanced manner in the preadjudication stage. This is the novelty of the author compared to existing studies, namely the author includes crime victims as study material in this paper, not only in the context of protecting the rights of suspects. For the problems mentioned above, a Pretrial institution model should be made by expanding the pretrial authority, namely that the victim can submit a 
Pretrial application for a victim's report or complaint according to the victim that the investigator is slow in handling it or the investigator does not process it without clear and legal reasons.

Thus the model that can be offered for strengthening pretrial institutions in the Indonesian criminal justice system if in the end in legal reform, especially the renewal of criminal procedural law in the criminal justice system, will maintain the pretrial institution.

The protection of the rights of suspects and victims, in addition to continuing to apply the Pretrial institution by strengthening it, can also be with the option or choice to apply the Preliminary Examining Judge or Commissioner Judge (Rechter Commissioner) which replaces the Pretrial institution, with an ideal concept concerning the Draft Criminal Procedure Code (RKUHAP) with several improvements.

The concept of the ideal model of the Judicial Commissioner institution if it is to be applied in the criminal justice system in Indonesia must be able to cover the weaknesses of the pretrial institution, by adopting or comparing it with the criminal justice system in several countries that have implemented the Preliminary Examination Judge (Judge Commissioner), but adapted to The Pancasila legal system essentially creates justice, certainty, and benefit based on Pancasila. The guidelines for the ideal model of the Judge Commissioner are as follows:

- The model of the Judicial Commissioner in the Indonesian criminal justice system must be based on Pancasila as a philosophical, juridical, and sociological foundation [22].

- The Judicial Commissioner's institutional model must cover the weaknesses of the pretrial institution, and be able to close the legal void spaces in the pretrial institution.

- The Judicial Commissioner's institutional model must be able to provide protection in substantial examinations in the pre-adjudication process, not only provide protection in examinations that are only in terms of formality or administrative matters.

- The model of the Board of Commissioners must be based on the concept of restorative justice, which builds participation and provides protection for the perpetrators, victims, and the community. This is because pretrial institutions currently only protect the rights of suspects.

- The model of the judge commissioner institution which is integrated into the integrated criminal justice system (Integrated Criminal Justice System) which is implemented by integrating between subsystems by making provisions governing the integrated criminal justice system starting from the sub-system of investigation, prosecution, court, and criminal execution, or which This is called the umbrella law or umbreu act. And the meaning of judicial power is not only limited to judicial power in a narrow sense but comprehensively [23].

- The Judicial Commissioner's institutional model has a proactive function, not passive, as is the function of the current pretrial institution which tends to be passive so that it cannot touch substantial issues.

- As a comparison, the model of the commissioner judge institution in several countries can be adopted in the model of the commissioner judge institution in Indonesia, including the commissioner judge in the Netherlands which is called the rechter commissioner, and in France the judge d'instruction, or the United States with the concept of the Habeas Corpus Act with a Preliminary Examination Judge (Magistrat) with a Pre-Trial procedure with an active role from the Magistrate. However, this model does not have to be fully adopted but adapted to the legal system in Indonesia which is based on Pancasila.

\section{CONCLUSION}

The protection of the rights of suspects and victims, in the pre-trial stage, which is currently implementing a pretrial institution, turns out to have weaknesses, because the pretrial institution is only a formality or formal, not substantial, and passive. In the renewal of criminal procedural law, especially in the related criminal justice system, namely in the Draft Criminal Procedure Code (RKUHAP), the application of pretrial institutions can be applied with two options, first continue to maintain the Pretrial institution by strengthening the authority of the Pretrial institution, or secondly by replacing the Pretrial institution by implementing the Commissioner Judge institution that carries out the function as a Preliminary Examination Judge which is passive and can carry out the function of substantial testing of the pre-trial process.

The ideal concept of a pretrial institution, if it is to be maintained in the reform of the criminal justice system, is to maintain the authorities of the pretrial institution after the decision of the Constitutional Court by adding the authority and function of the pretrial institution by overcoming the weaknesses and legal vacuums in the pretrial institution by protecting the rights of the pretrial institution. rights of suspects and victims, as well as granting authority that can grant substantial testing authority in the pre-adjudication stage. However, if you are going to implement the Judicial Commissioner institution by replacing the Pretrial institution, the ideal concept is the Judicial Commissioner institution which is based on Pancasila 
as the philosophical, juridical, and sociological foundation. Integrated Criminal Justice System) which is carried out by integration between subsystems by making provisions governing an integrated criminal justice system starting from the sub-system of investigation, prosecution, court, and criminal execution.

\section{REFERENCES}

[1] Nalom Kurniawan Barlyan, Penetapan Tersangka \& Praperadilan, Depok, PT. Raja Grafindo Persada, p. 1, 2020.

[2] Undang-undang Nomor 8 Tahun 1981 tentang Hukum Acara Pidana, diundangkan dalam Lembaran Negara Nomor 76 Tahun 1981 dan Tambahan Lembaran Negara Nomor 3209.

[3] D.Y. Witanto, Hukum Acara Praperadilan, Dalam Teori dan Praktik, Depok, Imaji Cipta Karya, p. 1, 2019.

[4] Antonius Benari Simbolon, Rekontruksi Hakim Komisaris \& Perlindungan Hak Asasi Tersangka di Indonesia, Jakarta, Kencana, p. 6.

[5] Yanto, Hakim Komisaris dalam Sistem Peradilan Pidana, Kepel Press, Yogyakarta, p. 16, 2013.

[6] Andi Hamzah, Hukum Acara Pidana Indonesia, Sinar Grafika, Jakarta, p. 56, 2008.

[7] Badan Pembinaan Hukum Nasional (BPHN), "Hakim Komisaris dalam Sistem Peradilan di Indonesia," Journal. 2011.

[8] Peter Mahmud Marzuki, Penelitian Hukum, edisi revisi, (Jakarta: Prenamedia Group, 2014), p. 133.

[9] Tim Pengajar Metode Penelitian Hukum, Metode Penelitian Hukum, Depok: FH UI, p. 12, 2000.

[10] Putusan MK Nomor 65/PUU-IX/2011 dated April 19, 2012.

[11] Putusan MK Nomor 21/PUU-XII/2014 dated 28 April 2015.
[12] Putusan Mahkamah Konstitusi Nomor 65/PUU-IX dan Putusan Nomor 21/PUU-XII, dalam Jurnal Hukum \& Pembangunan, Damian Agata Yuvens, Rangga Sujud Widigda, dan Aisyah Sharifa, Dilema Upaya Hukum Terhadap Penyadapan, accessed on 12 January 2021.

[13] Peraturan Mahkamah Agung Republik Indonesia Nomor 4 Tahun 2016 Tentang Larangan Peninjauan Kembali Putusan Praperadilan.

[14] Putusan Mahkamah Konstitusi Nomor 65/PUU-IX/2011 dated April 19, 2011.

[15] Surat Edaran Mahkamah Agung Nomor 1 Tahun 2018 tentang Larangan Pengajuan Praperadilan bagi Tersangka yang melarikan diri.

[16] Komisi Hukum Nasional, Penelitian Komisi Hukum Nasional, Hukumonline. Retrieved January 10, 2021.

[17] Putusan Mahkamah Konstitusi Nomor 102/PUU-XIII/2015 dated 30 July 2015. loc.cit.

[18] Surat Edaran Mahkamah Agung Nomor 1 Tahun 2018 tentang Larangan Pengajuan Praperadilan bagi Tersangka yang melarikan diri.

[19] Gebrandy Alfrendo Lalolorang, Kajian Yuridis Penetapan Sprindik berulangkali oleh Kejaksaan setelah gugatan Praperadilan Diterima (studi kasus La Nyalla Mattalitti), Jurnal, Neliti.com. 2016, accessed on January 11, 2021.

[20] Lilik Mulyadi, Upaya Hukum yang dilakukan Korban Kejahatan dikaji dari Perspektif Sistem Peradilan Pidana dalam Putusan Mahkamah Agung Republik Indonesia, Jurnal, badilum.mahkamahagung.go.id., accessed on January 11, 2021.

[21] Putusan Mahkamah Konstitusi Nomor 98/PUU-X/2012 dated 21 May 2013.

[22] Sovia Hasanah, Arti Landasan Filosofis, Sosiologis, dan Yuridis. Hukumonline was accessed on January 12, 2021

[23] Yanto, Hakim Komisaris Dalam Sistem Peradilan Pidana Yanto, 6th ed. Jakarta. IKAPI, 2013. 